\title{
THE COMBINED EFFECT OF HYPERVENTILATION AND HYPOTENSION ON CEREBRAL OXYGENATION IN ANAESTHETIZED DOGS
}

\author{
Richard M. Levin, Martin E. Zadigian and Steven C. Hall
}

\author{
ABSTRACT
}

This study was done to evaluate cerebral oxygenation in dogs under general anaesthesia with combined hyperventilation and hypotension. Cerebral and muscle oxygen tensions, cerebrospinal fluid lactate, pyruvate. and creatine phosphokinase (CPK) were measured to test for cerebral hypoxia.

Twenty dogs were anaesthetized with thiopentone $5 \mathrm{mg} \cdot \mathrm{kg}^{-1}$ and their tracheae were intubated. Anaesthesia was maintained with nitrous oxide and oxygen (50/50), halothane 0.5 per cent, pancuronium $0.1 \mathrm{mg} \cdot \mathrm{kg}^{-1}$ per $\mathrm{l}-2$ hours and ventilation was controlled. Five dogs were maintained at normocapnia and normotension, five dogs were hyperventilated to $\mathrm{Pa}_{\mathrm{a}} \mathrm{co}_{\mathrm{g}}$ $3.33 \mathrm{kPa}(25 \mathrm{~mm} \mathrm{Hg})$ while blood pressure was kept at baseline levels (hyperventilation alone), and 10 dogs were hyperventilated to $\mathrm{Pa}_{\mathrm{CO}_{2}} 3.33 \mathrm{kPa}(25 \mathrm{~mm} \mathrm{Hg})$ followed by deliberate hypotension to a mean arterial pressurc of $6.65 \mathrm{kPa}(50 \mathrm{~mm} \mathrm{Hg})$ with the use of nitroprusside and halothane (combined hyperventilation and hypotension).

Cerebrospinal fluid lactate increased significantly from control during hyperventilation alone, with an even greater increase to above $4 \mathrm{mmol} / \mathrm{l}$ during combined hyperventilation and hypertension. The incremental rise of lactate with combined hyperventilation and hypotension was significant at the end of the second hour of hypotension. Cerebrospinal fluid lactate/pyruvate ratios and $\mathrm{CPK}$ increased significantly above control only with combined hyperventilation and hypotension.

Oxygen tension of muscle and brain decreased from baseline with hyperventilation alone and decreased further to $2.66 \mathrm{kPa}(20 \mathrm{~mm} \mathrm{Hg}$ ) after combined hyperventilation and hypotension. Good correlation was found between changes in oxygen tension of muscle and brain in the three groups $(r-0.914, p<0.05$ and $r-0.908, p<0.05)$, respectively, for all groups combined.

Evidence is thus presented that the combination of hyperventilation and hypotension to accepted levels causes inadequate cerebral oxygen supply in anaesthetized dogs. Although muscle and brain oxygen tensions reflected the degree of cerebral hypoxia, their usefulness as clinical monitors is likely to be limited.

EXTENSIVE INTRACRANIAL OPERATIONS, such as those for large vascular tumors and craniofacial reconstructions, often call for controlled hyperventilation and deliberate hypotension. These

Richard M. Levin, M.D. Associate Professor of Anaesthesiology, Martin E. Zadigian, M.D., Associate of Clinical Anaesthesia. Steven C. Hall, M.D., Associate of Clinical Anaesthesia, Northwestern University and Children's Memorial Hospital, Chicago, Illinois 60614 U.S.A.

The work was done in the Department of Anesthesiology. Children's Memorial Hospital, Chicago It was supported in part by a National Institute of Health Grant, number RR05475-15, and in part by the Northwestern University Department of Anesthesia.

Presented at the annual meeting of the American Society of Anesthesiologists, Chicago, Illinois, October, 1978, and the annual meeting of the Anaesthesia Section. The American Academy of Paediatrics, Toronto, Ontario, April, 1979.

Reprints requests to: Richard M. Levin, M.D., Department of Anaesthesia. Children's Memorial Hospital, 2300 Children`s Plaza, Chicago, Illinois, 60614 U.S.A.

Canad. Anaesth. Soc. J., vol. 27, no. 3, May 1980 anaesthetic adjuncts combine cerebral vaso constriction and decreased cerebral perfusion to reduce brain size and produce a drier operative field for more precise surgical dissection and re duced blood loss. 1,2 Hyperventilation anc hypotension induced separately have beer shown to decrease brain oxygen tension anc internal jugular venous oxygen tension and to produce electroencephalographic changes as sociated with unconsciousness. ${ }^{3.4}$ In addition brain tissue and cerebrospinal fluid of test ani mals have shown decreased stores of high energ! phosphate (adenosine triphosphate and creatins phosphate), and increased lactate levels consis tent with moderate cerebral hypoxia. ${ }^{s-9}$

Since maintenance of cerebral blood flow witl decreased arterial blood pressure is dependent or concomittent decrease of cerebral vascular re sistance, added hyperventilation might interfer with compensatory mechanisms, reducing cere bral oxygenation. ${ }^{8,9}$ In addition, the left-shift 0 the haemoglobin oxygen dissociation curve in 
duced by hypocapnia and alkalosis resulting from hyperventilation should reduce cerebral oxygenation further. Previous investigators of the effects of hypotension on cerebral oxygenation took care to maintain normocapnia and warned of the dangers of combining hypotension and hyperventilation. ${ }^{10-13} \mathrm{Nilsson}{ }^{5}$ induced hypotension in rats to $3.99 \mathrm{kPa}(30 \mathrm{~mm} \mathrm{Hg})$ mean arterial pressure and found that hyperventilation added to $\mathrm{Pa}_{\left(\mathrm{O}_{2}\right.}$ of $20 \mathrm{~mm} \mathrm{Hg}$ (2.66 $\mathrm{kPa}$ ) aggravated the moderate increase in brain lactate and decrease in brain energy stores, indicating further reduction in cerebral blood flow.

It is evident that the combined effects of induced hyperventilation and hypotension on cerebral oxygenation might be deleterious and, if these anaesthetic adjuncts are to be advantageous, early identification of cerebral hypoxia is important. Electrocardiographic tracing, peripheral arterial and central venous pressures (CVP). urinary output and arterial blood gas tensions are all indirect but relatively insensitive measurements of tissue perfusion and oxygenation. It has been stressed that a significant decline in tissue oxygenation can occur with normal vital signs and blood gases. ${ }^{4}$

This study was done to evaluate cerebral oxygenation under conditions produced by general anaesthesia with combined hyperventilation and hypotension in dogs. Cerebrospinal fluid lactate, pyruvate and creatine phosphokinase (CPK) were used as indicators of the adequacy of cerebral oxygen supply, and oxygen tension of brain and muscle were tested as monitors of cerebral hypoxia.

\section{Methods and Materials}

Twenty unmedicated mongrel dogs weighing $10-13 \mathrm{~kg}$ were anaesthetized with thiopentone $5 \mathrm{mg} \cdot \mathrm{kg}^{-1}$ intravenously. After tracheal intubation anaesthesia was maintained with nitrous oxide and oxygen (50/50), halothane 0.5 per cent and pancuronium $0.1 \mathrm{mg} \cdot \mathrm{kg}^{-1}$ per $\mathbf{1 - 2}$ hours. Ventilation was controlled. The animals were placed supine on thermoregulatory blankets to maintain body temperature near $37^{\circ} \mathrm{C}$. End-tidal gas was sampled continuously through a catheter passed to the tip of the tracheal tube and carbon dioxide concentration was measured by an infrared analyser (Godart NV Capnograph). Peripheral venous and arterial cannulae were established in the left femoral region. The intravenous line served for maintenance of fluid administration with dextrose 5 per cent in sodium chloride 0.2 per cent solution and for nitroprusside infusion during the course of the experiment. The arterial line provided measurements of mean arterial pressure and samples for blood gas analysis.

A flow-directed \#7 French Swan-Ganz catheter with temperature-sensitive tip (Edwards \# 702027) was passed into the pulmonary artery from the right femoral vein for thermodilution cardiac output measurements (Edwards model 9520 computer). Each cardiac output determination was done in duplicate with $2 \mathrm{ml}$ of iced saline. The proximal port of the catheter served for central venous pressure measurements and the temperature sensitive tip sensed blood temperature $\left(\mathrm{Temp}_{\mathrm{B}}\right)$. Temperature was also recorded peripherally in the right deltoid muscle (Temp $\mathrm{s}_{\mathrm{s}}$ ) with a muscle temperature probe and Yellow Springs telethermometer. A urethral catheter was passed into the bladder and the urine volume was measured in a calibrated collecting system.

Tissue oxygen electrodes (IBC in Vivo tissue oxygen electrode, $\# 660-001,1.2$ French $\times 20 \mathrm{~cm}$ ) were introduced first through an 18 gauge needle into the deltoid muscle and then through a burr hole $(1 \mathrm{~cm}$ from the midline of the skull and $5 \mathrm{~cm}$ caudad to the orbital ridge) $1 \mathrm{~cm}$ deep into the right cerebral hemisphere. through an 18 gauge blunt-end needle. Muscle and brain oxygen tension $\left(\mathrm{Pm}_{\mathrm{O}_{2}}\right.$ and $\left.\mathrm{Pb}_{\mathrm{O}_{2}}\right)$ were recorded continuously with an IBC Multipurpose Oxygen Tension Recorder 145 MP-A. Tissue electrodes were checked for accuracy before and after each study with solutions of known oxygen tension (General Diagnostics, Blood Gas Control Solutions) at $37^{\circ} \mathrm{C}$. After completion of each experiment. the electrodes reliably measured oxygen tension within $\pm 0.266 \mathrm{kPa}( \pm 2 \mathrm{~mm} \mathrm{Hg}$ ) of the standard solutions.

Finally, a percutaneous cisternal puncture was accomplished with an 18-gauge Tuohy epidural needle, and an Abbott T-catheter was attached for cerebrospinal fluid sampling. Cerebrospinal fluid lactate, pyruvate, and CPK were measured in samples iced immediately and analyzed on the day of collection by enzymatic assay. ${ }^{14,15}$ Cisternal cerebrospinal fluid gas analysis was done immediately on samples obtained with glass syringes, using an IL 113 blood gas analyzer, calibrated before each determination. $\mathrm{PO}_{2}, \mathrm{PCO}_{2}$ and $\mathrm{pH}$ of arterial blood and cerebrospinal fluid were measured with standard Clark and Severinghaus glass electrodes. Bicarbonate values were computed using the Henderson-Hasselbach equation, taking into account the difference 
TABLE I

Protocol

\begin{tabular}{|c|c|c|c|c|c|c|}
\hline \multirow[b]{2}{*}{ Hour } & \multicolumn{2}{|c|}{ Group I $(n=5)$} & \multicolumn{2}{|c|}{ Group II $(n=5)$} & \multicolumn{2}{|c|}{ Group III $(n=10)$} \\
\hline & $\begin{array}{c}\mathrm{Pa}_{\mathrm{CO}_{2}} \\
\mathrm{kPa}\left(\mathrm{mmHg}^{2}\right)\end{array}$ & $\begin{array}{c}\text { MAP } \\
\mathrm{kPa}(\mathrm{mmHg})\end{array}$ & $\begin{array}{c}\mathrm{Pa}_{\mathrm{Co}_{2}} \\
\mathrm{kPa}(\mathrm{mmHg})\end{array}$ & $\begin{array}{c}\mathrm{MAP} \\
\mathrm{kPa}(\mathrm{mmHg})\end{array}$ & $\begin{array}{c}\mathrm{Pa}_{\mathrm{CO}_{2}} \\
\mathrm{kPa}(\mathrm{mmHg})\end{array}$ & $\begin{array}{c}\mathrm{MAP} \\
\mathrm{kPa}(\mathrm{mmHg})\end{array}$ \\
\hline 1 & $5.32(40)$ & $13.3(100)$ & $5.32(40)$ & $13.3(100)$ & $5.32(40)$ & $13.3(100)$ \\
\hline 2 & $5.32(40)$ & $13.3(100)$ & $3.33(25)$ & $13.3(100)$ & $3.33(25)$ & $13.3(100)$ \\
\hline 3 & $5.32(40)$ & $13.3(100)$ & $3.33(25)$ & $13.3(100)$ & $3.33(25)$ & $6.65(50)$ \\
\hline 4 & $5.32(40)$ & $13.3(100)$ & $3.33(25)$ & $13.3(100)$ & $3.33(25)$ & $6.65(50)$ \\
\hline 5 & $5.32(40)$ & $13.3(100)$ & $3.33(25)$ & $13.3(100)$ & $3.33(25)$ & $13.3(100)$ \\
\hline 6 & $5.32(40)$ & $13.3(100)$ & $5.32(40)$ & $13.3(100)$ & $5.32(40)$ & $13.3(100)$ \\
\hline
\end{tabular}

between $\mathrm{pK}$ and carbon dioxide solubility in plasma and cerebrospinal fluid.

Continuous readings of end-tidal carbon dioxide concentration provided information for coarse adjustment of ventilator settings; blood gas analysis was used for fine adjustment. After a one-hour baseline period at $\mathrm{Pa}_{\mathrm{CO}_{2}} 4.66-5.32 \mathrm{kPa}$ (35-40 $\mathrm{mm} \mathrm{Hg}$ ) and mean arterial pressure of approximately $13.3 \mathrm{kPa}(100 \mathrm{~mm} \mathrm{Hg})$ the animals were randomly assigned to one of three groups (Table I).

\section{Group I (5 dogs) (Control)}

$\mathrm{Pa}_{\mathrm{CO}_{2}}$ and mean arterial pressure were maintained near baseline levels for six hours.

\section{Group II (5 dogs) (Hyperventilation)}

$\mathrm{Pa}_{\mathrm{CO}_{2}}$ was lowered to $3.33 \mathrm{kPa}(25 \mathrm{~mm} \mathrm{Hg})$ and mean arterial pressure was maintained near baseline levels for four hours. Hyperventilation was then discontinued and normocapnia and normotension were maintained for an additional hour.

\section{Group III (10 dogs) (Hyperventilation and Hypotension)}

$\mathrm{Pa}_{\mathrm{CO}_{2}}$ was lowered to $3.3 \mathrm{kPa}(25 \mathrm{~mm} \mathrm{Hg}$ ) for one hour. Hypotension was then added using halothane 1.5 per cent and nitroprusside 0.01 per cent infusion, varying the rate to achieve mean arterial pressure of $6.65 \mathrm{kPa}(50 \mathrm{~mm} \mathrm{Hg})$. Nitroprusside dose rate was kept below $10 \mu \mathrm{g} \cdot \mathrm{kg}^{-1} \cdot \mathrm{min}^{-1}$ and the total dose below $1.0 \mathrm{mg} \cdot \mathrm{kg}^{-1}$. The combination of hypotension and hyperventilation was maintained for two hours. Hyperventilation was then continued for one hour with blood pressure returned to baseline levels (nitroprusside discontinued, halothane reduced to 0.5 per cent). Finally hyperventilation was discontinued with normocapnia and normotension maintained for one additional hour.

Mean arterial pressure, central venous pres- sure, $\mathrm{Pm}_{\mathrm{O}_{2}}, \mathrm{~Pb}_{\mathrm{O}_{2}}$, Temp $\mathrm{M}$ and Temp $\mathrm{T}_{\mathrm{B}}$ were measured continuously and recorded hourly. $\mathrm{Pa}_{\mathrm{CO}_{2}}$ was measured frequently until the desired level was reached and remained steady, and then recorded hourly. Cardiac index (CI), arterial blood and cerebrospinal fluid gas analyses, cerebrospinal fluid lactate, pyruvate and CPK were measured at the end of each hourly segment. Urinary output was maintained near base-line levels by varying the rate of infusion of intravenous fluid.

The data are presented as the means with 95 per cent confidence limits calculated from the range, a highly efficient measure of dispersion for ten or fewer observations. ${ }^{16}$ Student's t-test was used to compare differences between group means at the end of each hourly segment. $\mathrm{P}<0.05$ was considered significant. Spearman rank correlation ${ }^{17}$ was used to determined correlation coefficients and their $p$ values.

\section{RESULTS}

$\mathrm{Pa}_{\mathrm{CO}_{2}}$ and mean arterial pressure in all three groups of dogs are shown in Table II. $\mathrm{Pa}_{\mathrm{CO}_{2}}$ was maintained in a narrow range near $3.33 \mathrm{kPa}$ $(25 \mathrm{~mm} \mathrm{Hg}$ ) during hyperventilation in groups II and III. Mean arterial pressure remained consistently around $13.3 \mathrm{kPa}(100 \mathrm{~mm} \mathrm{Hg})$ until deliberate hypotension lowered the blood pressure in the hyperventilation and hypotension group to a narrow range at $6.65 \mathrm{kPa}(50 \mathrm{~mm} \mathrm{Hg})$.

Cardiocirculatory and temperature changes monitored during the study period are shown in Tables III and IV. Although cardiac rate increased significantly from control with combined hyperventilation and hypotension all other measurements of circulatory adequacy remained near control levels. Central (Temp $p_{B}$ ) and peripheral $\left(\right.$ Temp $_{M}$ ) temperatures were maintained between $36^{\circ}$ and $38^{\circ} \mathrm{C}$

Figure 1 shows the variation in cerebrospinal fluid lactate, lactate/pyruvate ratio, and CPK in 
TABLE II

\begin{tabular}{|c|c|c|c|c|c|c|}
\hline \multirow[b]{2}{*}{ Hours } & \multicolumn{3}{|c|}{$\mathrm{Pa}_{\mathrm{CO}_{2}} \mathrm{kPa}(\mathrm{mmHg})$} & \multicolumn{3}{|c|}{$\begin{array}{c}\mathrm{MAP}-\mathrm{kPa}(\mathrm{mmHg}) \\
\text { Group }\end{array}$} \\
\hline & I & II & III & I & II & III \\
\hline 1 & $\begin{array}{l}5.05 \pm 0.93 \\
(38 \pm 7)\end{array}$ & $\begin{array}{l}6.12 \pm 0.67 \\
(46 \pm 5)\end{array}$ & $\begin{array}{l}5.32 \pm 0.67 \\
(40 \pm 5)\end{array}$ & $\begin{array}{l}13.43 \pm 0.93 \\
(101 \pm 7)\end{array}$ & $\begin{array}{c}13.70 \pm 0.93 \\
(103 \pm 7)\end{array}$ & $\begin{array}{c}13.43 \pm 0.8 \\
(101 \pm 6)\end{array}$ \\
\hline 2 & $\begin{array}{l}5.45 \pm 0.27 \\
(41 \pm 2)\end{array}$ & $\begin{array}{c}3.46^{*} \pm 0.4 \\
\left(26^{*} \pm 3\right)\end{array}$ & $\begin{array}{c}3.33^{*} \pm 0.4 \\
\left(25^{*} \pm 3\right)\end{array}$ & $\begin{array}{l}13.57 \pm 0.8 \\
(102 \pm 6)\end{array}$ & $\begin{array}{c}13.43 \pm 0.93 \\
(101 \pm 7)\end{array}$ & $\begin{array}{c}13.57 \pm 0.8 \\
(102 \pm 6)\end{array}$ \\
\hline 3 & $\begin{array}{l}5.59 \pm 0.4 \\
(42 \pm 3)\end{array}$ & $\begin{array}{c}3.19^{*} \pm 0.27 \\
\left(24^{*} \pm 2\right)\end{array}$ & $\begin{array}{l}3.33^{*} \pm 0.4 \\
\left(25^{*} \pm 3\right)\end{array}$ & $\begin{array}{c}13.70 \pm 0.93 \\
(103 \pm 7)\end{array}$ & $\begin{aligned} & 14.23 \pm 0.93 \\
&(107 \pm 7)\end{aligned}$ & $\begin{array}{c}6.65 * \dagger \pm 0.13 \\
\left(50^{*} \dagger \pm 1\right)\end{array}$ \\
\hline 4 & $\begin{array}{l}5.32 \pm 0.27 \\
(40 \pm 2)\end{array}$ & $\begin{array}{l}3.33^{*} \pm 0.4 \\
\left(25^{*} \pm 3\right)\end{array}$ & $\begin{array}{c}3.33^{*} \pm 0.4 \\
\left(25^{*} \pm 3\right)\end{array}$ & $\begin{array}{l}13.83 \pm 0.93 \\
(104 \pm 7)\end{array}$ & $\begin{array}{c}13.43 \pm 0.8 \\
(101 \pm 6)\end{array}$ & $\begin{array}{c}6.65^{*} \dagger \pm 0.13 \\
\left(50^{*} \dagger \pm 1\right)\end{array}$ \\
\hline$s$ & $\begin{array}{l}5.32 \pm 0.27 \\
(40 \pm 2)\end{array}$ & $\begin{array}{l}3.33^{*} \pm 0.27 \\
\left(25^{*} \pm 2\right)\end{array}$ & $\begin{array}{l}3.59^{*} \pm 0.27 \\
\left(27^{*} \pm 2\right)\end{array}$ & $\begin{array}{l}13.43 \pm 0.93 \\
(101 \pm 7)\end{array}$ & $\begin{array}{l}13.70 \pm 0.93 \\
(103 \pm 7)\end{array}$ & $\begin{array}{c}12.37 \pm 0.8 \\
(93 \pm 6)\end{array}$ \\
\hline 6 & $\begin{array}{l}5.59 \pm 0.27 \\
(42 \pm 2)\end{array}$ & $\begin{array}{l}5.85 \pm 0.53 \\
(44 \pm 4)\end{array}$ & $\begin{array}{l}5.45 \pm 0.67 \\
(41 \pm 5)\end{array}$ & $\begin{array}{c}13.57 \pm 0.8 \\
(102 \pm 6)\end{array}$ & $\begin{array}{c}13.57 \pm 0.8 \\
(102 \pm 6)\end{array}$ & $\begin{array}{l}13.3 \pm 0.27 \\
(100 \pm 2)\end{array}$ \\
\hline
\end{tabular}

*Significant difference between group and group $I(p<0.05)$.

$\dagger$ Significant difference between group II and group III $(\mathrm{p}<0.05)$.

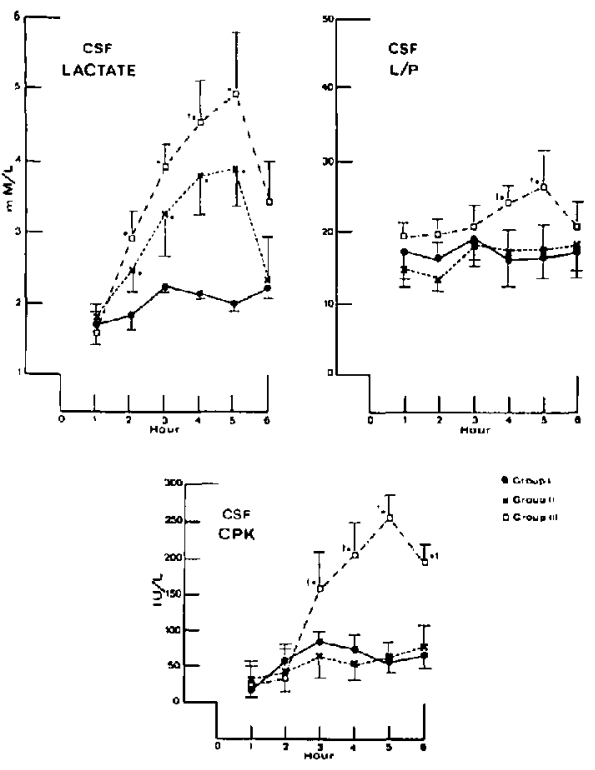

FIGURE 1 The variation in cerebrospinal fluid lac. tate, lactate/pyruvate (L/P) ratio, and CPK in all three groups. Mean values $\pm 95 \% \mathrm{CL}$. (See text.)

* Significant difference between group and group I $(\mathrm{p}<0.05)$.

tSignificant difference between group II and group III $(\mathrm{P}<0.05)$.

all three groups. Baseline values for all three groups were similar. Cerebrospinal fluid lactate increased significantly from control during hyperventilation alone, with an even greater in- crease to above $4 \mathrm{mmol} / \mathrm{l}$ during combined hyperventilation and hypotension. The incremental rise of lactate in group III above group II was significant at the end of the second hour of hypotension. Lactate/pyruvate ratios increased significantly above control only with combined hyperventilation and hypotension. Increase in cerebrospinal fluid lactate and lactate/pyruvate ratio did not begin to fall in animals with combined hyperventilation and hypotension until hyperventilation was discontinued.

Hyperventilation alone did not increase CPK values above the controls (Figure 1). However, combined hyperventilation and hypotension increased cerebrospinal fluid CPK above both groups I and II. CPK continued to rise after hypotension was discontinued and did not begin to fall until hyperventilation was also discontinued. In the combination of hyperventilation with hypotension CPK remained significantly above control one hour after returning to normocapnia and normotension.

Oxygen tension variations in the arterial blood $\left(\mathrm{Pa}_{\mathrm{O}_{2}}\right)$, cerebrospinal fluid (Pcsf $\left.\mathrm{O}_{2}\right)$, muscle and brain are shown in Figure 2. $\mathrm{Pa}_{\mathrm{O}_{2}}$ and $\mathrm{Pcsf}_{\mathrm{O}_{2}}$ remained well above $6.65 \mathrm{kPa}(50 \mathrm{~mm} \mathrm{Hg})$ in all groups.

Baseline $\mathrm{Pm}_{\mathrm{O}_{2}}$ values for all three groups were similar. Baseline $\mathrm{Pb}_{\mathrm{O}_{2}}$ values for the three groups, varied greatly, however. $\mathrm{Pm}_{\mathrm{O}_{2}}$ and $\mathrm{Pb}_{\mathrm{O}_{2}}$ were significantly less than control (Group I) after three hours of hyperventilation alone and during combined hyperventilation and hypotension. $\mathrm{PO}_{2}$ in muscle and brain declined to $2.66 \mathrm{kPa}(20 \mathrm{~mm}$ 


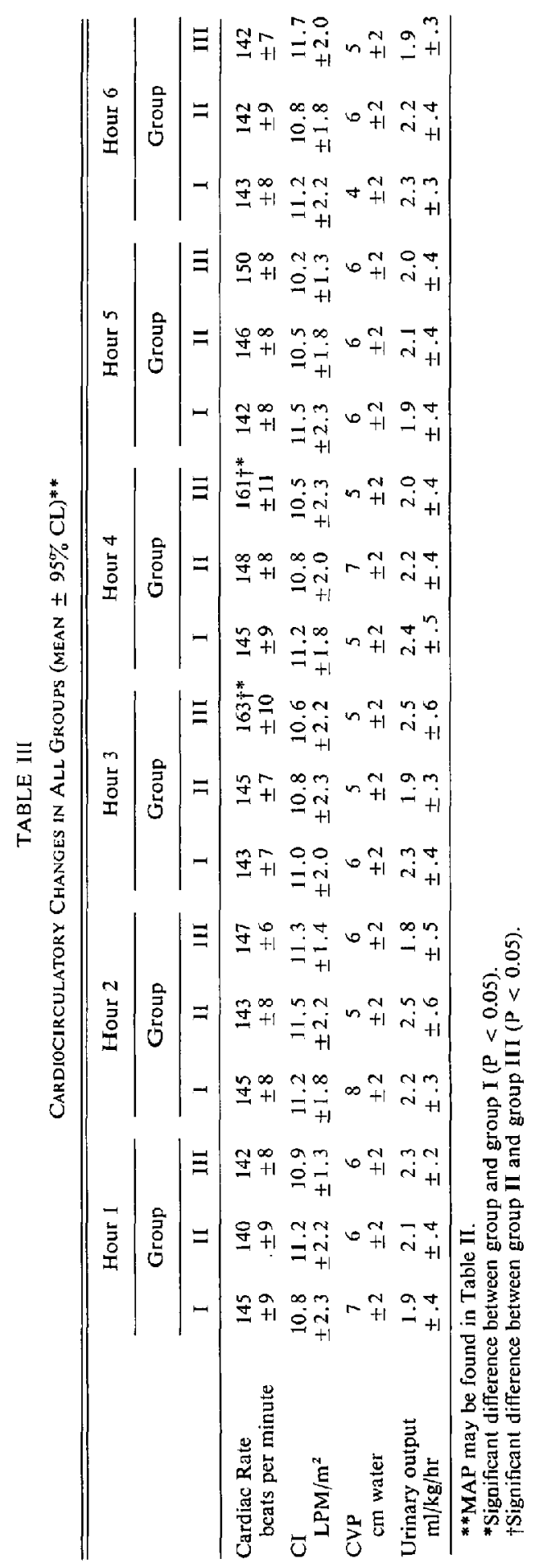


TABLE IV

Initial and Final Temperature Levels in All Groups (MEan $\pm 95 \% \mathrm{CL}$ )*

\begin{tabular}{|c|c|c|c|c|c|c|}
\hline & \multicolumn{3}{|c|}{ Initial hour of experiment } & \multicolumn{3}{|c|}{ Final hour of experiment } \\
\hline & 1 & 11 & 111 & $\mathbf{I}$ & II & III \\
\hline $\begin{array}{l}\operatorname{TEMP}_{\mathrm{M}} \\
{ }^{\circ} \mathrm{C}\end{array}$ & $\begin{array}{r}36.7 \\
\pm 0.5\end{array}$ & $\begin{array}{r}36.8 \\
\pm 0.6\end{array}$ & $\begin{array}{r}36.4 \\
\pm 0.4\end{array}$ & $\begin{array}{r}36.5 \\
\pm 0.5\end{array}$ & $\begin{array}{r}36.7 \\
\pm 0.4\end{array}$ & $\begin{array}{r}36.8 \\
\pm 0.5\end{array}$ \\
\hline $\begin{array}{l}\text { TEMP } \\
{ }^{\circ} \mathrm{C}\end{array}$ & $\begin{array}{r}36.9 \\
\pm 0.3\end{array}$ & $\begin{array}{r}36.8 \\
\pm 0.4\end{array}$ & $\begin{array}{r}37.2 \\
\pm 0.3\end{array}$ & $\begin{array}{r}36.8 \\
+0.4\end{array}$ & $\begin{array}{r}36.8 \\
\pm 0.5\end{array}$ & $\begin{array}{r}36.9 \\
\pm 0.5\end{array}$ \\
\hline
\end{tabular}

* Final values not significantly different from initial values within groups; also no significant difference between $T E M P_{B}$ and $T E M P_{M}$ initial or final values.

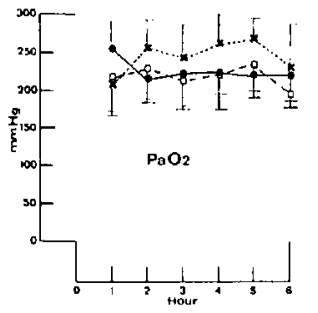

$\mathrm{PCSF}_{2}$
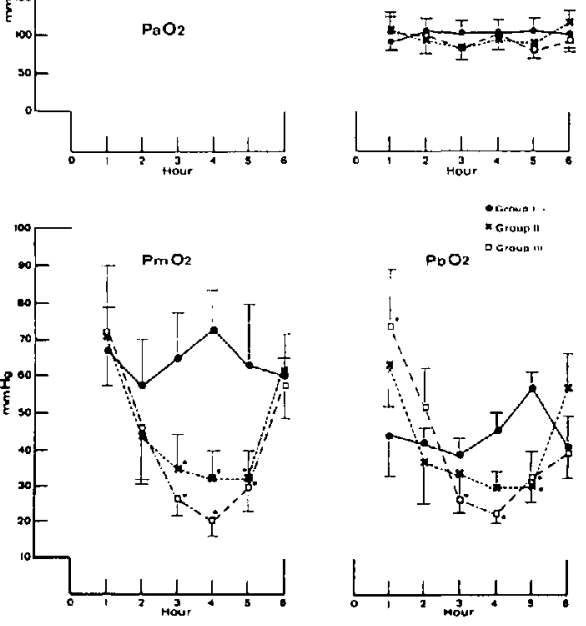

Figure 2 Oxygen tension variation in the arterial blood $\left(\mathrm{Pa}_{\mathrm{O}_{2}}\right)$, cerebrospinal fluid $\left(\mathrm{Pcsf}_{\mathrm{O}_{2}}\right)$, muscle $\left(\mathrm{Pm}_{\mathrm{O}_{2}}\right)$ and brain $\left(\mathrm{Pb}_{\mathrm{O}_{2}}\right)$. Mean values $\pm 95 \% \mathrm{CL}$. (See text.)

*Significant difference between group and group I $(p<0.05)$. There was no significant difference between group II and group III values.

$\mathrm{Hg}$ ). Tissue $\mathrm{PO}_{2}$ in groups $\mathrm{II}$ and III returned towards baseline values after normotension and normocapnia were achieved.

Good correlation was found between charges in $\mathrm{Pm}_{u_{2}}$ and $\mathrm{Pb}_{\mathrm{u}_{2}}$ in the three groups $(r-0.959$, $\mathrm{p}<0.05$ ). There was good inverse correlation between $\mathrm{Pb}_{\mathrm{O}_{2}}$ and cerebrospinal fluid lactate and CPK $(r-0.914, p<0.05$ and $r-0.908$, $p<0.05$, respectively, for all groups combined.

As seen in Table $V$, cerebrospinal fluid carbon dioxide tension remained approximately $0.66 \mathrm{kPa}(5 \mathrm{~mm} \mathrm{Hg})$ higher than $\mathrm{Pa}_{\mathrm{CO}_{2}}$ during hyperventilation. The change in cerebrospinal fluid carbon dioxide tension and $\mathrm{cH}^{+}(\mathrm{pH})$ was similar in groups II and III. There was no evidence in the cerebrospinal fluid metabolic acidosis developing during the study period.

\section{Discussion}

The anaesthetic technique in this experiment closely approximates that normally used for extensive intracranial operations at Chicago Children's Memorial Hospital. $\mathrm{Pa}_{\mathrm{CO}_{2}}$ was lowered to $3.33 \mathrm{kPa}(25 \mathrm{~mm} \mathrm{Hg})$ and mean arterial pressure to $6.65 \mathrm{kPa}(50 \mathrm{~mm} \mathrm{Hg})$ since these are commonly recommended safe levels for neuroanaesthesia. ${ }^{2.10 .11}$ Halothane was introduced before as opposed to the customary $10-15 \mathrm{~min}$ utes after hyperventilation. so that initial measurements could be made at normocapnia with a control level of halothane. It is our current practice to induce hypotension with the combination of halothane and nitroprusside for procedures requiring decreased perfusion pressures for under two hours. Pentolinium has been the agent of choice for longer periods of deliberate hypotension. Nitroprusside was chosen here because it provides a greater degree of controllability for the relatively brief duration of hypotension.

Hypotension was readily induced with the combination of nitroprusside and halothane, and blood pressure was controlled within a narrow range near $6.65 \mathrm{kPa}(50 \mathrm{~mm} \mathrm{Hg})$. None of the animals required nitroprusside infusion in excess of the recommended rate or total dose. 7

\section{Cerebrospinal Fluid Lactate}

Cerebrospinal fluid lactate has been used as an index of insufficient oxygen supply to the brain. ${ }^{18}$ Cerebral hypoxia increases cerebrospinal fluid lactate by stimulating glycolysis in brain cells. ${ }^{18}$ Alkalosis has also been shown to increase cere- 


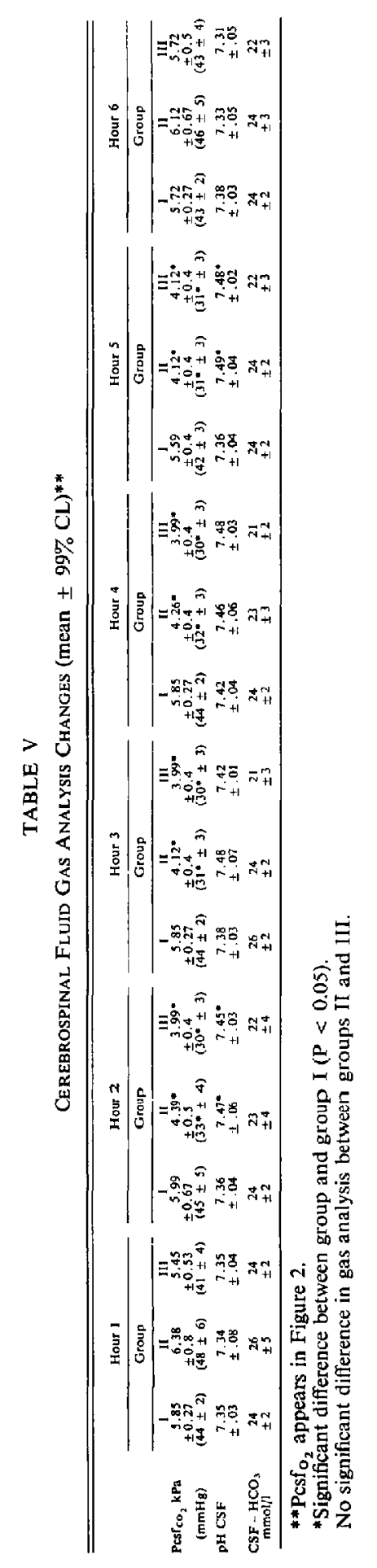


bral lactate production. ${ }^{19}$ If alkalosis were the sole cause for the rise in cerebrospinal fluid lactate in this study, there should be no difference between levels during hyperventilation alone and during combined hyperventilation and hypotension at the same level of alkalosis. However, the results show an incremental rise in lactate with hyperventilation and hypotension as compared to hyperventilation alone, at the same $\mathrm{cH}^{+}(\mathrm{pH})$ of cerebrospinal fluid. This difference was significant at the end of the second hour of hypotension. Therefore, at least part of the increased cerebrospinal fluid lactate seen during combined hyperventilation and hypotension is likely due to cerebral hypoxia.

Further evidence that the raised cerebrospinal fluid lactate is due to cerebral hypoxia is provided by the lactate/pyruvate ratio data. The lactate/pyruvate ratio, an indicator of increased anacrobic glycolysis, ${ }^{18}$ was elevated only after combined hyperventilation and hypotension and not after hyperventilation alone.

\section{Cerebrospinal Fluid Creatine Phosphokinase}

Since several investigators have cautioned against interpreting increased lactate alone as conclusive proof of tissue hypoxia ${ }^{19-21}$ cerebrospinal fluid CPK was also measured to detect cerebral derangement. Hypoxia causes release of CPK from damaged cells and increased CPK has been found in the cerebrospinal fluid in acute cerebral vascular accidents, encephalitis and head trauma. ${ }^{22-24}$ Cerebrospinal fluid CPK has several advantages as an index of brain damage, since it is principally derived from the central nervous system, does not normally cross the blood-brain barrier, ${ }^{23}$ is not found in red blood cells which may contaminate cerebrospinal fluid samples,,$^{24}$ and appears to be correlated with the severity of central nervous system damage. ${ }^{22}$

Cerebrospinal fluid CPK increased to over three times the control during combined hyperventilation and hypotension, providing further evidence of cerebral hypoxia. The failure of cerebrospinal fluid lactate, lactate/pyruvate ratio, and CPK to fall until after hyperventilation was discontinued in group III animals suggests that the decreased cerebral oxygen supply resulting from combined hyperventilation and hypotension continues even after blood pressure returns to normal, as long as $\mathrm{Pa}_{\mathrm{CO}_{2}}$ remains near $3.33 \mathrm{kPa}$ (25 $\mathrm{mm} \mathrm{Hg}$ ).

\section{Tissue Oxygen Tension}

Mass spectrometer studies have indicated that measurements of skeletal muscle gas tensions should provide an index of peripheral tissue perfusion. More specifically, tissue oxygen tensions, which represent the net balance between oxygen supply and utilization at the cellular level, should reflect decreases in blood oxygen content, cardiac output and/or peripheral perfusion. Furuse, et al. ${ }^{25}$ have shown that skeletal muscle oxygen tension provides an excellent direct index of peripheral perfusion, even small decreases in cardiac output being rapidly reflected by decreased skeletal muscle oxygen tension. Since this may be measured with fine-gauge oxygen electrodes which are readily implanted in appropriate tissues, we chose to measure cerebral and muscle oxygen tensions as monitors of hypoxia.

Two further points relative to tissue oxygen electrodes must be discussed before considering the results of their use in this study. Although the electrodes are fine-gauge, they are too large to measure intracellular oxygen tension. More likely, levels represent extracellular oxygen tension. In addition, halothane and nitrous oxide have been shown to increase oxygen tension recordings of tissue oxygen electrodes in vitro. ${ }^{26}$ If this effect occurs in vivo, it should be minimized in this study by the constant level of low-dose halothane inspired by group I and II animals; and even with the higher halothane concentration used during hypotension in group III animals the continued fall in tissue oxygen tension to very low levels argucs against a significant halothane effect.

The wide variation in the baseline $\mathrm{Pb}_{\mathrm{O}_{2}}$ between the three groups probably represents positioning of the electrode tip in different areas of the brain. However, $\mathrm{Pb}_{\mathrm{O}_{2}}$ consistently decreased to $2.66 \mathrm{kPa}(20 \mathrm{~mm} \mathrm{Hg})$ with combined hyperventilation and hypotension, a level often associated with central nervous system derangement. ${ }^{4.27}$ $\mathrm{Pb}_{\mathrm{O}_{2}}$ fell as metabolic evidence of cerebral hypoxia increased. The good correlation between the fall in cerebral tissue oxygen tension and rise in both cerebrospinal fluid lactate and $\mathrm{CPK}$, indicate that $\mathrm{Pb}_{\mathrm{O}_{2}}$ would be an excellent monitor of cerebral tissue oxygenation. However, if the problems associated with $\mathrm{Pb}_{\mathrm{O}_{2}}$ measurement (such as maintenance of sterility and avoidance of brain trauma) are taken into consideration, its usefulness as a routine monitor in the clinical setting will be limited.

The close correlation of $\mathrm{Pm}_{\mathrm{O}_{2}}$ and $\mathrm{Pb}_{\mathrm{O}_{2}}$ is an interesting finding, since $\mathrm{Pm}_{\mathrm{O}_{2}}$ levels could readily be followed in an accessible muscle during a wide variety of operations. However, it must be 
pointed out that the animals in this study were in stable cardiocirculatory status, with no evidence of hypovolaemia that would drastically change perfusion of the brain relative to muscle. Therefore, while $\mathrm{Pm}_{0.2}$ should prove to be an excellent clinical monitor of peripheral tissue perfusion and oxygenation, its use as an accurate guide to cerebral oxygenation will depend at least on the adequacy of circulating blood volume.

Lastly, it is again evident from this study that cardiac rate, systemic blood pressure, central venous pressure, urinary output and arterial blood gas tensions may not indicate the slate of tissue ox ygenation.

\section{SUMMARY}

This study was done to evaluate cerebral oxygenation in dogs under conditions produced by general anaesthesia with combined hyperventilation and hypotension. Cerebral and muscle tissue oxygen tensions, cerebrospinal fluid lactate, pyruvate, and creatine phosphokinase were measured to test for cerebral hypoxia.

The evidence presented indicates that the combination of hyperventilation and hypotension to commonly accepted levels causes insufficiency of cerebral oxygen supply in anaesthetized dogs. Although muscle and cerebral oxygen tension measurements reflect the degree of cerebral hypoxia, their usefulness as clinical monitors are likely to be limited.

\section{ACKNOWLEDGEMENTS}

The authors gratefully acknowledge the valu able advice and assistance of Doctor Lawrence Tomasi, Head of Neurology, Children's Memorial Hospital and of Doctor Harry Linde, Vice Chairman of Research, Department of Anaesthesiology. Northwestern University Medical School, Chicago, Illinois. We also thank Terry Purnell, Paul Gora and Luke Bold for their technical assistance.

\section{REFERENCES}

1. Eckenhoff, J.E. Deliberate hypotension. Anesthesiology 48: 87 (1978).

2. Michenfelder, J.D., Gronert, G.A. \& RehDER, K. Neuroanesthesia. Anesthesiology 30: 65 (1969).

3. SUGIOKA, K. \& DAvis, D.A. Hyperventilation with oxygen - a possible cause of cerebral hypoxia. Anesthesiology 21: 135 (1960).
4. McDowall, D.G. Monitoring the brain. Anesthesiology 45: 117 (1976).

5. Nilsson. L. \& Siesjö. B.K. The effect of deep halothane hypotension upon labile phosphates and upon extra- and intracellular lactate and pyruvate concentrations in the rat brain. Acta Physiol. Scand. 81: 508 (1971).

6. SmlTh, A.L. Barbiturate protection in cerebral hypoxia. Anesthesiology 47: 285 (1977).

7. Michenfelder, J.D. \& Theye, R.A. Canine systemic and cerebral effects of hypotension induced by hemorrhage, trimetaphan, halothane or nitroprusside. Anesthesialogy 46: 188 (1977).

8. HARPER. A.M. \& GLASs, H.l. Effect of alterations in the arterial carbon dioxide tension on the blood flow through the cerebral cortex at normal and low arterial blood pressures. J. Neurol. Neurosurg. Psychiat. 28: 449 (1965).

9. OKuda, Y. MCDowall, D.G.. ALI, M.M. el al. Changes in $\mathrm{CO}_{2}$ responsiveness and in autoregulation of the cerebral circulation during and after halothane-induced hypotension, J. Neurol. Neurosurg. Psychiat. 39: 221 (1976).

10. HARP, J.R. \& WOLL.MAN, H. Cerebral metabolic effects of hyperventilation and deliberate hypotension. Brit. J. Anesth. 45: 256 (1973).

11. ShEnkin, H.A. \& Bouzarth. W.F. Clinical methods of reducing intracranial pressure. New Eng. J. Med. 282: 1465 (1970).

12. SAlem, M.R., WONG. A.Y., BennliTl, E.J., et al. Deliberate hypotension in infants and children. Anesth. and Anal. 53: 975 (1974).

13. Thompson, G.E., Miller. R.D., Stevens. W.C. ef al. Hypotensive anesthesia for total hip arthroplasty: a study of blood loss and organ function (brain, heart, liver and kidney). Anesthesiology 48: 91 (1978).

14. Marbach. E.P. \& Weil. M.H. Rapid enzymatic measurement of blood lactate and pyruvate. Clinical Chem. 13: 314 (1967).

15. RosALKI, S.B. An improved procedure for serum CPK determination. J. Lab. Clin. Med. 69: 696 (1967).

16. DeAn, R.B. \& Dixon, W.J. Simplified statistics for small number of observations. Analytical Chem. 23: $636(1951)$.

17. SiEgeL, S. Nonparametric Statistics for the Behavioral Sciences. New York: McGraw-Hill (1956), pp. 202-213.

18. SıEsıö. B.K. Brain Energy Metabolism. New York: John Wiley and Sons (1978), pp. 417-428.

19. Plum. F., Posner, J.B. \& Smith, W.W. Effect of hyperbaric-hyperoxic hyperventilation on blood. brain, and CSF lactate. Am. J. Physiol. 215: 1240 (1968).

20. CoHEN, R.D. \& SimPSON, R. Lactate metabolism. Anesthesiology 43: 661 (1975)

21. Sıfs.ö, B.K. The influence of respiratory disturbances on acid-base and energy metabolisin of the brain. Intens. Care Med. 3: 245 (1977).

22. MAAS, A.I.R. Cerebrospinal fluid enzymes in acute brain injury 2 . Relation of CSF enzyme activity to extent of brain injury. J. Neurol., Neurosurg. and Psychiat. 40: 666 (1977).

23. SHerWIN, A.L., Norris, J.W. \& Bulcke, J.A. Spinal fluid creatine kinase in neurological disease. Neurology 19: 993 (1969). 
24. WOLINTZ, A.H. JaCOBS, L.D. ChRISTOFF. N. et al.. Serum and cerebrospinal fluid enzymes in cerebrovascular disease. Arch. Neurol. 20:54 (1969).

25. Furuse, A., Brawley, R.K., Struve, E., el al. Skeletal muscle gas tension: Indicator of cardiac output and peripheral tissue perfusion. Surgery 74 : $2 / 4$ (1973).
26. MCHUGH, R.D.. EPSTEIN. R.M. \& LONGNICKER, D.E. Halothane mimics axygen in oxygen microelectrodes. Anesthesiology 50:47(1979).

27. ECKENHOFF, J.E.. Hal.e Enderby, G. E., LarSON, A.. et al. Human cerebral circulation during deliberate hypotension and head-up tilt. J. Appl. Physiol. 18: 1130 (1963).

\section{RÉSUMÉ}

Cette étude a pour objectif l'évaluation de l'oxygénation cérébrale du chien hyperventilé et hypotendu sous anesthésie générale. La tension en oxygène cérébral et musculaire, le lactate. pyruvate et la créatine-phosphokinase (CPK) du liquide céphalo-rachidien ont servis de tests de mesure de l'hypoxie cérébrale.

Vingt chiens ont été anesthésiés au thiopentone $5 \mathrm{mg} \cdot \mathrm{kg}^{-1}$ et intubés. L'anesthẻsie a été maintenue au protoxyde-oxygène $(50 / 50)$, à l'halothane 0.5 pour cent et au pancuronium $0.1 \mathrm{mg} \cdot \mathrm{kg}^{-1}$ pendant une période d'une à deux heures sous ventilation contrôlée. Cinq chiens ont été maintenus en normocapnic et normotension, cinq furent hyperventilés à une $\mathrm{Pa}_{\mathrm{CO}_{2}}$ de $3.33 \mathrm{kPa}(25 \mathrm{mmHg})$ tout en maintenant la pression artérielle à la valeur initiale de base (hyperventilation seule), et 10 chiens furent hyperventilés à une $\mathrm{Pa}_{\mathrm{CO}_{2}}$ de $3.33 \mathrm{kPa}(25 \mathrm{mmHg}$ ) après quoi on a produit une hypotension artérielle jusqu'à une valeur moyenne de $6.65 \mathrm{kPa}$ $(50 \mathrm{mmHg}$ ) avec du nitroprussiate de soude et de l'halothane (hyperventilation et hypotension).

Pendant l'hyperventilation seule, le lactate céphalo-rachidien a augmenté de façon significative comparativement au contrôle; cette augmentation s'est accrue jusqu'à plus de $4 \mathrm{mmol} / \mathrm{l}$ lorsque l'hyperventilation a été associée à l'hypotension. Cet accroissement progressif du lactate lors de l'association hyperventilation-hypotension a été significative à la fin de la deuxième heure d'hypotension. Le rapport lactate-pyruvate du liquide céphalorachidien et la CPK n'ont augmenté de façon significative que lors de l'association hyperventilation-hypotension.

La tension en oxygène du muscle et du cerveau a diminué comparativement à la valeur initiale de base de façon significative avec l'hyperventilation seule, alors que la chute atteignait $2.66 \mathrm{kPa}(20 \mathrm{mmHg})$ avec l'association hyperventilation-hypotension. On a trouvé une bonne corrélation entre les changements de tension en oxygène musculairee et cérébral pour les trois gruupes $(r-0.914, p<0.05$ et $r-0.908, p<0.05)$ respectivement el pour tous les groupes réunis.

Ces donnćes prouvent que l'association hyperventilation-hypotension à des niveaux généralement acceptés cause une insuffisance de l'apport d'oxygène cérébral chez le chien anesthésié. Bien que les tensions en oxygène du muscle et du cerveau réflètent le degré d'hypoxie, leur utilité comme moniteurs clinique est probablement limitée. 